\title{
Social and public health implications of the legalisation of recreational cannabis: A literature review
}

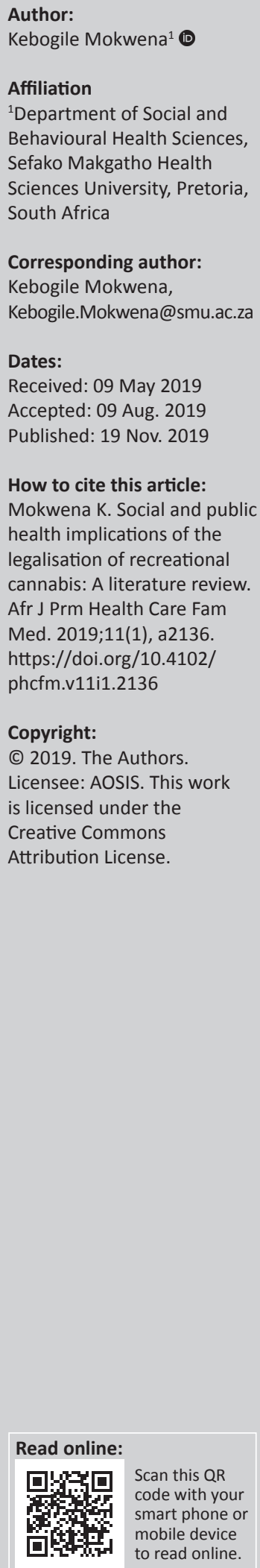

Background: After many years of legal struggles for the legalisation of recreational use of cannabis, the Constitutional Court of South Africa ruled in favour of the applicants in September 2018. Although the ruling issued caution regarding the social challenges accompanying this legalisation, it did not address how the country would deal with the societal consequences of this ruling.

Aim: The aim of this article was to discuss the social and public health implications of the legalisation of recreational cannabis on South Africa.

Methods: Literature review on the social, health and legal impacts of legalisation of cannabis, considering experiences of other countries that have legalised cannabis.

Results: The legalisation brings a range of significant negative consequences, which include an expected increase in the number of users and the subsequent undesirable effects on the physical, mental and social health of communities.

Conclusion: In terms of financial, infrastructural and human resources, South Africa cannot afford the consequences of the legalisation of recreational cannabis. Poor communities, children and the youth will carry the brunt of the scourge of cannabis use.

Keywords: cannabis legislation; social outcomes; health outcomes; recreational use; legal system; injuries; Constitutional Court.

\section{Introduction}

After a history of cannabis being outlawed for centuries, the Constitutional Court of South Africa ruled in favour of the legalisation of recreational cannabis in September 2018. Many South Africans, as well as government departments, view this ruling as a direct barrier to the goal of promoting health and well-being of the citizens, which is the mandate of public health programmes. Although many proponents of cannabis legalisation welcome the ruling, it is expected to trigger many consequences that will negatively influence health behaviour and health outcomes. ${ }^{1}$ The consequences are an increased demand on the health and social systems in the country, which had been under strain prior to this ruling. Cannabis use further contributes to poor adherence to antiretroviral therapy and management of HIV-related symptoms amongst HIV-infected individuals, ${ }^{2}$ as well as worsening of disease progression for TB-infected persons, ${ }^{3}$ which increases the burden of these two epidemics. The judgement further requires a legislative amendment to accommodate the change, and thus the need for policy makers and health service providers to consider the impact of this ruling, as well as the implications on the social and public health services.

Cannabis is the most commonly accessed illicit drug in South Africa, ${ }^{4}$ and the age of initiation of its use is reported to be between 11 and 12. The low price of cannabis enables widespread early initiation of use, low quit rate and a longer duration of use. ${ }^{5}$ The younger users are therefore vulnerable to disruptions in brain development, with long-term implications. The legalisation leads to an increase in the number of not only users, but also the under-age users and youth, who do not enjoy any specific protection despite their vulnerability. ${ }^{6,7}, 8$ Moreover, as the number of users increases, so does the support and social acceptability, which diminishes the efforts to discourage its use. ${ }^{9}$

\section{Why the legalisation?}

As in other countries, the legalisation of cannabis was driven by grassroots movements, ${ }^{10}$ with the main driver being the concept of self-determination, which argues that in a democracy the extent to which the state can be enabled to interfere and control personal aspects of the citizens' lives is 
challenged. The self-determination concept includes behaviours that affect individuals' health outcomes, as in the case of cannabis use. This argument was significantly used to challenge the outlawing of cannabis in many countries, including in South Africa. The agenda of cannabis legalisation is therefore driven by self-interest and self-determination, which do not necessarily support, promote or enable the principles of health promotion. Moreover, the current and past use of cannabis is more likely to be in favour of legalisation ${ }^{9,11}$ and often underestimates or even downplays its harmful effects. ${ }^{12}$ The consequences of legalisation of cannabis use therefore make it difficult to minimise the adverse effects of the drug. ${ }^{13}$

\section{Health and social impacts of legalisation of cannabis}

The health arguments against the use of cannabis include its addictive nature, ${ }^{14}$ and that it is both a gateway and reverse gateway for hard drugs. ${ }^{15}$ It has also been directly linked to a range of adverse outcomes in physical health, which include lung cancer, ${ }^{16}$ impaired respiratory function, cardiovascular disease, ${ }^{17}$ elevated systolic blood pressure, ${ }^{18}$ stroke, ${ }^{19}$ mental disorders, ${ }^{20,21,22}$ which include schizophrenia, especially amongst young people, ${ }^{23,24}$ undesirable cognitive changes $^{25}$ and disruption of normal brain development if used during adolescence. ${ }^{26}$

Cannabis has been reported to have adverse effects during pregnancy on both the mother and the baby. ${ }^{27,28}$ An offspring who is exposed to cannabis in utero is likely to engage in early indulgence of cannabis use. ${ }^{29}$ Cannabis use also contributes to a range of criminal activities. ${ }^{30,31}$ The educational and social impacts of cannabis use include poor academic performance and non-completion of studies, $32,33,34,35,36$ compromise in performing executive functions and challenges in social adjustment and vocational success. ${ }^{37}$ These challenges are likely to extend to the later life ${ }^{38}$ too and thus affect the ability to keep a job..$^{39,40,41}$

Other researchers concluded that cannabis is associated with an increased frequency of both traffic ${ }^{42,43}$ and non-traffic injuries ${ }^{44}$ With the high prevalence of violence and injuries in South Africa, ${ }^{45,46}$ it is reasonable to conclude that cannabis use contributes to many of the accidents, injuries and deaths on South African roads. This has been explained by cannabis use being associated with impaired driver cognition, $37,47,48,49$ psychomotor impairment and resultant car crashes..$^{50,51,52}$

Cannabis use has also been associated with workplace injuries, where it presents with challenges for workplace productivity. ${ }^{53,54,55,56}$ Poor workplace productivity thus impacts on the economic performance of the country and is likely to increase with the legalisation of cannabis for recreational purposes. With the increasing rates of cannabis use, a relatively new clinical condition known as the Cannabinoid Hyperemesis Syndrome continues to be reported, which is characterised by episodes of nausea and vomiting, thus increasing evidence of the negative effect of cannabis on the gastrointestinal tract. A key symptom of this syndrome is a peculiar compulsive hot bathing pattern, which suggests an adverse effect on the central nervous system. ${ }^{57,58,59,60}$ However, the pathophysiology of this syndrome is not well understood and requires further investigation.

Cannabis use also increases the risk of poor mental health of the population, which can only be improved if the country makes the prevention and treatment of mental and substance use disorders a public health priority. ${ }^{61,62}$ However, this priority comes at a price that the country can hardly afford. Roadside testing for deterring driving after cannabis use is recommended, ${ }^{63}$ and this increases the demand for lawenforcement officers and technology to carry out such tests. It will also increase the proportion of people who depend on welfare. ${ }^{64}$ The increased demand also extends to services required to combat a range of health and social challenges, which include road traffic accidents, mental disorders as well as violence and severe crimes committed under the influence of substance abuse..$^{30,65}$ Alcohol is by far the major substance of abuse, whereas cannabis is the most common illicit drug used, especially amongst youths, because it is easy to grow and cheap to buy. ${ }^{66}$

Although cannabis use continues to gain social acceptance, its association with potential adverse effects on pregnant women and their offspring poses a threat; thus, there is a need for specific interventions for this specific group of health-services recipient ${ }^{28}$ to combat the resultant adverse effects on pregnant women and their neonates.

Quitting cannabis use is difficult, expensive, takes a long time and is often unsuccessful. Once addicted, many users in South Africa need and want treatment services, but often have difficulty accessing such services. ${ }^{67}$ This results in substance abuse treatment utilisation being low amongst people from disadvantaged communities because of inequitable access to substance abuse treatment services. ${ }^{68}$ Barriers to treatment include stigma towards individuals with substance use disorders and negative beliefs about the quality and effectiveness of treatment. The scourge of cannabis use is therefore disproportionately borne by poor people who lack services for treatment and support, should they wish to quit. ${ }^{69}$

\section{Legalisation and potential increase in use}

The impact of the legalisation of cannabis ruling will thus increase the demand and use, with associated social and health problems on both a short- and long-term basis, because of increased availability, greater social acceptance and possibly lower prices. ${ }^{70,71}$ The legalisation of recreational cannabis use is likely to increase both the amount of use amongst current users and increase the number of new users. ${ }^{72,73}$ Literature also shows that the impact of decriminalisation is concentrated amongst minors, who have 
a higher rate of uptake, especially in the period immediately after decriminalisation. ${ }^{74}$ The consequences of such an increase include a demand for legislative, health and social services, which can be human, infrastructural and financial, which are currently under strain.

\section{Legalised cannabis and the legal system}

Although the current discussion on legalisation limits cannabis use to private homes, and children are meant to be protected from exposure, there are no specific measures to protect children who live in such homes. Such children are likely to be subjected to passive smoking of cannabis, with negative health outcomes, which include altered consciousness and even coma in some infants. ${ }^{75,76,77,78}$

The legalisation of cannabis is likely to further compromise the public security conditions in the country, as it will serve as a gateway to the use of harder drugs. ${ }^{79}$ The intended regulation for use, for example protecting minors, will be very difficult to implement, as strategies for such regulations are not in place. Currently, South Africa is already struggling to regulate the sales and use of alcohol and cigarettes, and an additional demand for the regulation of cannabis will increase the demand for regulation that is not likely to be met or implemented effectively without additional resources. There are therefore legal implications of this ruling, which require regulations that will prioritise public health over recreation by users and profits by cultivators and sellers of cannabis. ${ }^{80}$ This ruling does not, therefore, support efforts to prevent and reduce the harmful effects that result from the recreational use of cannabis, and South African policymakers need to develop strategic and comprehensive controls to achieve minimum harm associated with cannabis use.

\section{The socio-economic impact of cannabis legalisation}

Globally, poverty is associated with poor healthcompromising behaviours, and cannabis dependence is greater amongst communities that are socio-economically compromised..$^{70,81}$ The increase in the use of cannabis, which is a result of legalisation, will thus continue to increase the socio-economic disparity in South Africa, pushing more black people, who are more likely to use cannabis, to the lower end of the social class. ${ }^{4,82}$ Literature reports that in communities where substance abuse is rife, residents experience associated trauma, and they use addictive substances to cope with the negative psychological effects of trauma, resulting in a vicious cycle. ${ }^{83}$ Moreover, the Constitutional Court acknowledged that the legalisation of cannabis will result in a range of social problems, which the country needs to deal with. The ruling does not therefore address any remedies for the resultant social ills, which include mental health, crime and other challenges associated with the consequences of the ruling.

Although substance abuse in South Africa is high, there is lack of evidence-based interventions to combat the scourge.
Currently, the country is battling with challenges to strengthen health systems to enable acceptable standards for ordinary healthcare services, and not much is streamlined towards the prevention of use of substances. The legalisation of cannabis thus comes at a time when its impact is likely to worsen the likelihood of channelling both human and financial resources towards prevention. The identification of vulnerable groups and interventions for prevention is currently much needed, ${ }^{84}$ and this need is expected to increase following the legalisation.

\section{Discussion}

The status of cannabis as a gateway drug to a range of other illicit drugs use amongst individuals with mental disorders ${ }^{85}$ is a major concern for public health in South Africa. Although there have been arguments to emphasise the benefits of medical use of cannabis, such benefits are outweighed by the negative data, some of which are indicated in this article. Moreover, safe and effective alternative treatments are readily available, which can be given under medical advice. The legalisation of smoked cannabis is likely to cause significant public health risks, which will be a burden on the health system services in South Africa, and in the meantime pose a serious danger to a wide range of people.

The current increasing burden of mental illness has not been appropriately addressed, either in interventions to prevent or manage or treat the increasing numbers. The potential increase in the number of cannabis users, following this legalisation, is expected to worsen the situation as it increases the number of people who need treatment for addiction and other mental disorders that emanate from cannabis use. Cannabis use is associated with complications, considered to be serious because they lead to hospitalisation. ${ }^{86}$

One of the major public health challenges in South Africa is road accidents, specifically, driving under the influence of alcohol, ${ }^{87,88}$ which continues relentlessly despite various interventions by traffic officials and the police services. The situation is expected to increase significantly with cannabis use which, although incapacitates the user, cannot be easily detected.$^{89}$ It is the view of some public health and behaviour scientists that the road accidents carnage needs to be approached as a public health matter, and not be considered a matter of policing or law enforcement.

The link between poverty and substance abuse $\mathrm{e}^{90,91,92}$ is more pronounced amongst the poor who do not play any role in the fight for legalisation. The disparity between classes of people will thus be more pronounced than ever before. ${ }^{82}$ Even more concerning is the fact that the effects of cannabis use are passed on to future generations of the user. ${ }^{93}$

The legalisation of cannabis is expected to have an adverse impact on the health and social well-being of South Africans. The Constitutional Court, which ruled in favour of legalisation of cannabis, gave the parliament 2 years to amend the Drugs and Drugs Trafficking Act to accommodate this change. It is not 
clear how the parliament intends to approach this task to achieve minimum harm that results from the changes brought about by this ruling. The South African Ministries of Justice and Constitutional Development, Police, Health, Social Development, the National Director of Public Prosecutions, Doctors for Life and other Non Governmental Organisations (NGOs) that opposed the legalisation find themselves in a difficult position where they have to deal with the aftermath of a ruling that they did not support, a ruling which does not support or promote the health of the public.

Experiences from countries that legalised cannabis before South Africa include the increase in the uptake of the drug with resultant increase in road accidents and injuries. The legalisation, therefore, requires comprehensive strategies to keep the drug out of the reach of minors whilst increasing awareness and knowledge on the harmful effects of the drug. To get better insights on how to develop an appropriate framework to legalise marijuana, Canada should closely watch the development in its neighbouring country, the USA, where some of its states like Colorado, Oregon, Washington and Alaska have already legalised recreational use of marijuana..$^{94}$

\section{Conclusion}

In the USA, challenges of legalisation include an ineffective overarching federal regulatory structure, and an industry that seeks to exploit loopholes to maximise profit, ${ }^{95}$ which are the same issues that apply in South Africa. In industrialised countries like Canada, with adequate resources for prevention, management and treatment for cannabis addiction, legislation of cannabis has failed to protect the youth. ${ }^{7}$ The youth of South Africa are already vulnerable because of widespread prevalence of substance abuse, common ones being nyaope, 'tik' and cocaine, which the country has not been able to address satisfactorily. Lessons learnt from countries that have legalised cannabis indicate that South Africa cannot afford the costs of the consequences of the legalisation of cannabis, as it comes with demands on infrastructure, human, social, health services and financial resources brought about by a ruling of the highest court in the land. The poor and vulnerable communities, with the least programmes and resources for prevention and treatment, will continue to bear the brunt of the consequences of this ruling.

\section{Acknowledgements}

\section{Competing interests}

The author declares that no competing interests exist.

\section{Author(s) contributions}

I declare that I am the sole author of this research article.

\section{Ethical considerations}

This article followed all ethical standards for a research without direct contact with human or animal subjects.

\section{Funding information}

This research received funding from the South African Medical Research Council (SAMRC) and the National Research Foundation.

\section{Data availability statement}

Data sharing is not applicable to this article as no new data were created or analysed in this study.

\section{Disclaimer}

The views and opinions expressed in this article are those of the author and do not necessarily reflect the official policy or position of any affiliated agency of the author.

\section{References}

1. Volkow ND, Swanson JM, Evins AE, et al. Effects of cannabis use on human behavior, including cognition, motivation, and psychosis: A review. JAMA Psychiatr. 2016;73(3):292-297. https://doi.org/10.1001/jamapsychiatry.2015.3278

2. Bonn-Miller MO, Oser ML, Bucossi MM, Trafton JA. Cannabis use and HIV antiretroviral therapy adherence and HIV-related symptoms. J Behav Med. 2014;37(1):1-0. https://doi.org/10.1007/s10865-012-9458-5

3. Thu K, Hayes M, Miles S, Tierney L, Foy A. Marijuana 'bong' smoking and tuberculosis. Int Med J. 2013;43(4):456-458. https://doi.org/10.1111/ imj.12089

4. Ramlagan S, Peltzer K, Matseke G. Epidemiology of drug abuse treatment in South Africa. S Afr J Psychiatr. 2010;16(2):40-49. https://doi.org/10.4102/sajpsychiatry. v16i2.172

5. Van Ours JC, Williams J. Cannabis prices and dynamics of cannabis use. J Health Econ. 2007;26(3):578-596. https://doi.org/10.1016/j.jhealeco.2006.10.001

6. Pacula RL, Powell D, Heaton P, Sevigny EL. Assessing the effects of medical marijuana laws on marijuana use: The devil is in the details. J Pol Anal Manag. 2015;34(1):7-31. https://doi.org/10.1002/pam.21804

7. Kelsall D. Cannabis legislation fails to protect Canada's youth. CMAJ. 2017;189(21):E737-E738. https://doi.org/10.1503/cmaj.170555

8. Fischer B, Rehm J. Cannabis use, legalization and youth health. CMAJ. 2017;189(29):E971. https://doi.org/10.1503/cmaj.733215

9. Palali A, van Ours JC. Cannabis use and support for cannabis legalization. Empir Econ. 2017;53(4):1747-1770. https://doi.org/10.1007/s00181-016-1172-7

10. Blickman T. Cannabis policy reform in Europe. Bottom up rather than top down Series on Legislative Reform of Drug Policies. Amsterdam: Transnational Institute; 2014:28.

11. Williams J, Van Ours JC, Grossman M. Why do some people want to legalize cannabis use? National Bureau of Economic Research [homepage on the Internet]. 2011. [cited 18 February 2018]. Available from: https://www.nber.org/papers/w16795.pdf

12. Williams J, van Ours JC, Grossman M. Attitudes to legalizing cannabis use. Health Economics. 2016;25(9):1201-1216. https://doi.org/10.1002/hec.3340

13. Hall W. Challenges in minimizing the adverse effects of cannabis use after legalization. Soc Psychiatry Psychiatr Epidemiol. 2015;50(7):1013-1015. https:// doi.org/10.1007/s00127-015-1067-5

14. Hurd YL, Michaelides M, Miller ML, Jutras-Aswad D. Trajectory of adolescent cannabis use on addiction vulnerability. Neuropharmacology. 2014:76:416-424. https://doi.org/10.1016/j.neuropharm.2013.07.028

15. Badiani A, Boden JM, De Pirro S, Fergusson DM, Horwood LJ, Harold GT. Tobacco smoking and cannabis use in a longitudinal birth cohort: Evidence of reciprocal causal relationships. Drug and alcohol dependence. 2015;150:69-76. https://doi. org/10.1016/j.drugalcdep.2015.02.015

16. Aldington $\mathrm{S}$, Harwood $\mathrm{M}, \mathrm{Cox} B$, et al. Cannabis use and risk of lung cancer: $A$ case-control study. Eur Respir J. 2008;31(2):280-286. https://doi.org/10.1183/ 09031936.00065707

17. Hall W, Degenhardt L. Adverse health effects of non-medical cannabis use. Lancet 2009;374(9698):1383-1391. https://doi.org/10.1016/S0140-6736(09)61037-0

18. Alshaarawy O, Elbaz HA. Cannabis use and blood pressure levels: United States National Health and Nutrition Examination Survey, 2005-2012. J Hypertens. 2016;34(8):1507. https://doi.org/10.1097/HJH.0000000000000990

19. Singh NN, Pan Y, Muengtaweeponsa S, Geller TJ, Cruz-Flores S. Cannabis-related stroke: Case series and review of literature I Stroke Cerebrovasc Dis. 2012;21(7):555-560. https://doi.org/10.1016/j.jstrokecerebrovasdis.2010.12.010

20. Monshouwer K, Van Dorsselaer S, Verdurmen J, Ter Bogt T, De Graaf RO, Vollebergh W. Cannabis use and mental health in secondary school children: Findings from a Dutch survey. Br J Psychiatr. 2006;188(2):148-153. https://doi.org/10.1192/ bjp.188.2.148 
21. Paruk S, Burns JK, Caplan R. Cannabis use and family history in adolescent first episode psychosis in Durban, South Africa. I Child Adolesc Ment Health. 2013;25(1):61-68. https://doi.org/10.2989/17280583.2013.767264

22. Saban A, Flisher A, Laubscher R, London L, Morojele N. The association between psychopathology and substance use: Adolescent and young adult substance users in inpatient treatment in Cape Town, South Africa. Pan Afr Med J. 2014;17(Suppl 1):1-7. https://doi.org/10.11604/pamjs.supp.2014.17.1.3044

23. Casadio P, Fernandes C, Murray RM, Di Forti M. Cannabis use in young people: The risk for schizophrenia. Neurosci Biobehav Rev. 2011;35(8):1779-1787. https://doi. org/10.1016/j.neubiorev.2011.04.007

24. Degenhardt L, Coffey C, Romaniuk $\mathrm{H}$, et al. The persistence of the association between adolescent cannabis use and common mental disorders into young adulthood. Addiction. 2013;108(1):124-133. https://doi.org/10.1111/j.1360-0443.2012.04015.x

25. Crean RD, Crane NA, Mason BJ. An evidence based review of acute and long-term effects of cannabis use on executive cognitive functions. J Addiction Med. 2011;5(1):1. https://doi.org/10.1097/ADM.0b013e31820c23fa

26. Ashtari M, Cervellione K, Cottone J, Ardekani BA, Kumra S. Diffusion abnormalities in adolescents and young adults with a history of heavy cannabis use. J Psychiat Res. 2009;43(3):189-204. https://doi.org/10.1016/j.jpsychires.2008.12.002

27. Chapman SL, Wu LT. Substance use among adolescent mothers: A review. Child Youth Serv Rev. 2013;35(5):806-815. https://doi.org/10.1016/j.childyouth.2013. 02.004

28. Gunn JK, Rosales CB, Center KE, et al. Prenatal exposure to cannabis and maternal and child health outcomes: A systematic review and meta-analysis. BMJ Open. 2016;6(4):e009986. https://doi.org/10.1136/bmjopen-2015-009986

29. Volkow ND, Baler RD, Compton WM, Weiss SR. Adverse health effects of marijuana use. N Engl J Med. 2014 Jun 5;370(23):2219-2227. https://doi.org/10.1056/ NEJMra1402309

30. Van Heerden MS, Grimsrud AT, Seedat S, Myer L, Williams DR, Stein DJ. Patterns of substance use in South Africa: Results from the South African Stress and Health study. S Afr Med J. 2009;99(5):358-366.

31. Pedersen W, Skardhamar T. Cannabis and crime: Findings from a longitudinal study. Addiction. 2010;105(1):109-118. https://doi.org/10.1111/j.1360-0443. 2009.02719.x

32. Flisher AJ, Townsend L, Chikobvu P, Lombard CF, King G. 2010. Substance use and psychosocial predictors of high school dropout in Cape Town, South Africa. J Res Adolescence. 20(1):237-255. https://doi.org/10.1111/j.1532-7795.2009.00634.x

33. Verweij KJ, Huizink AC, Agrawal A, Martin NG, Lynskey MT. Is the relationship between early-onset cannabis use and educational attainment causal or due to common liability? Drug Alcohol Depend. 2013;133(2):580-586. https://doi. common liability? Drug Alcohol Dep
org/10.1016/j.drugalcdep.2013.07.034

34. Meier MH, Hill ML, Small PJ, Luthar SS. Associations of adolescent cannabis use with academic performance and mental health: A longitudinal study of upper with academic performance and mental health: A longitudinal study of upper
middle class youth. Drug Alcohol Depend. 2015;156:207-212. https://doi. middle class youth. Drug Alcohol Dep
org/10.1016/j.drugalcdep.2015.09.010

35. Arria AM, Caldeira KM, Bugbee BA, Vincent KB, O'Grady KE. The academic consequences of marijuana use during college. Psychol Addict Behav. 2015;29(3):564. https://doi.org/10.1037/adb0000108

36. Suerken CK, Reboussin BA, Egan KL, et al. Marijuana use trajectories and academic outcomes among college students. Drug Alcohol Depend. 2016;162:137-145. https://doi.org/10.1016/j.drugalcdep.2016.02.041

37. Andrade C. Cannabis and neuropsychiatry, 1: Benefits and risks. J Clin Psychiatr 2016;77(5):e551-e554. https://doi.org/10.4088/JCP.16f10841

38. Fergusson DM, Boden JM. Cannabis use and later life outcomes. Addiction. 2008;103(6):969-976. https://doi.org/10.1111/j.1360-0443.2008.02221.x

39. Compton WM, Gfroerer J, Conway KP, Finger MS. Unemployment and substance outcomes in the United States 2002-2010. Drug Alcohol Depend. 2014;142:350353. https://doi.org/10.1016/j.drugalcdep.2014.06.012

40. Lee JY, Brook JS, Finch SJ, Brook DW. Trajectories of marijuana use from adolescence to adulthood predicting unemployment in the mid 30s. Am J Addict. 2015 Aug;24(5):452-459. https://doi.org/10.1111/ajad.12240

41. Zhang C, Brook JS, Leukefeld CG, Brook DW. Trajectories of marijuana use from adolescence to adulthood as predictors of unemployment status in the early forties. Am J Addict. 2016 Apr;25(3):203-209. https://doi.org/10.1111/ajad.12361

42. Pulido J, Barrio G, Lardelli $P$, et al. Cannabis use and traffic injuries. Epidemiol. 2011;22(4):609-610. https://doi.org/10.1097/EDE.0b013e31821db0c2

43. Asbridge M, Hayden JA, Cartwright JL. Acute cannabis consumption and motor vehicle collision risk: Systematic review of observational studies and metaanalysis. BMJ. 2012;344:e536. https://doi.org/10.1136/bmj.e536

44. Barrio G, Jiménez-Mejías E, Pulido J, Lardelli-Claret P, Bravo MJ, de la Fuente L. Association between cannabis use and non-traffic injuries. Accid Anal Prev. 2012;47:172-176. https://doi.org/10.1016/j.aap.2012.01.002

45. Norman R, Matzopoulos R, Groenewald P, Bradshaw D. The high burden of injuries in South Africa. Bull World Health Organ. 2007;85:695-702. https://doi. org/10.2471/BLT.06.037184

46. Mayosi BM, Flisher AJ, Lalloo UG, Sitas F, Tollman SM, Bradshaw D. The burden of non-communicable diseases in South Africa. Lancet. 2009;374(9693):934-947. https://doi.org/10.1016/S0140-6736(09)61087-4

47. Lasebikan VO. Is cannabis use related to road crashes? A study of long distance commercial drivers in Nigeria. Afr J Drug Alcohol Stud. 2010;9(1):23-32. https:// doi.org/10.4314/ajdas.v9i1.61755
48. Gadegbeku B, Amoros E, Laumon B. Responsibility study: Main illicit psychoactive substances among car drivers involved in fatal road crashes. In Annals of advances in substances among car drivers involved in fatal road crashes. In Annals of advances in Association for the Advancement of Automotive Medicine. PMID: PMC3256820.

49. Bondallaz P, Chtioui H, Favrat B, Fornari E, Giroud C, Maeder P. Assessment of cannabis acute effects on driving skills: Laboratory, simulator, and on-road studies. In Handbook of cannabis and related pathologies. 2017; p. 379-390. Academic Press. https://doi. of cannabis and related pathologies. 2017;
org/10.1016/B978-0-12-800756-3.00045-4

50. Richer I, Bergeron J. Driving under the influence of cannabis: Links with dangerous driving, psychological predictors, and accident involvement. Accid Anal Prev. 2009;41(2):299-307. https://doi.org/10.1016/j.aap.2008.12.004

51. Hartman RL, Huestis MA. Cannabis effects on driving skills. Clin Chem. 2013;59(3):478-492. https://doi.org/10.1373/clinchem.2012.194381

52. Romano E, Torres-Saavedra P, Voas RB, Lacey JH. Marijuana and the risk of fatal car crashes: What can we learn from FARS and NRS data? The J Prim Prev. 2017;38(3):315-328. https://doi.org/10.1007/s10935-017-0478-3

53. Gates P, Roxburgh A, Copeland J. Cannabis and other drug use in the Australian workforce: Findings from the 2007 NDSHS data. National Cannabis Prevention and Information Centre Bulletin. 2009;8:1-9.

54. Pidd K, Roche AM, Buisman-Pijlman F. Intoxicated workers: Findings from a national Australian survey. Addiction. 2011;106(9):1623-1633. https://doi. org/10.1111/j.1360-0443.2011.03462.x

55. Goldsmith RS, Targino MC, Fanciullo GJ, et al. Medical marijuana in the workplace: Challenges and management options for occupational physicians. J Occup Environ Med. 2015;57(5):518. https://doi.org/10.1097/JOM.0000000000000454

56. Wettlaufer A, Florica RO, Asbridge M, et al. Estimating the harms and costs of cannabis-attributable collisions in the Canadian provinces. Drug Alcohol Depend. 2017;173:185-190. https://doi.org/10.1016/j.drugalcdep.2016.12.024

57. Sontineni SP, Chaudhary S, Sontineni V, Lanspa SJ. Cannabinoid hyperemesis syndrome: Clinical diagnosis of an underrecognised manifestation of chronic cannabis abuse. World J Gastroenterol. 2009;15(10):1264. https://doi. org/10.3748/wjg.15.1264

58. Galli J, Andari Sawaya R, Friedenberg F. Cannabinoid hyperemesis syndrome. Curr Drug Abuse Rev. 2011;4(4):241-249. https://doi.org/10.2174/1874473711104040241

59. Wallace EA, Andrews SE, Garmany CL, Jelley MJ. Cannabinoid hyperemesis syndrome: Literature review and proposed diagnosis and treatment algorithm. South Med J. 2011;104(9):659-664. https://doi.org/10.1097/SMJ.0b013e3182297d57

60. Simonetto DA, Oxentenko AS, Herman ML, Szostek JH. Cannabinoid hyperemesis: A case series of 98 patients. Mayo Clin Proc. 2012;87(2):114-119. Elsevier. https:// doi.org/10.1016/j.mayocp.2011.10.005

61. Myers B, Fakier N, Louw J. Stigma, treatment beliefs, and substance abuse treatment use in historically disadvantaged communities. Afr J Psychiatr. 2009;12(3):218-222. https://doi.org/10.4314/ajpsy.v12i3.48497

62. Whiteford HA, Degenhardt L, Rehm J, et al. Global burden of disease attributable to mental and substance use disorders: Findings from the Global Burden of Disease Study 2010. Lancet. 2013;382(9904):1575-1586. https://doi. org/10.1016/S0140-6736(13)61611-6

63. Watson TM, Mann RE. International approaches to driving under the influence of cannabis: A review of evidence on impact. Drug Alcohol Depend. 2016;169:148155. https://doi.org/10.1016/j.drugalcdep.2016.10.023

64. Pedersen W. Cannabis and social welfare assistance: A longitudinal study. Addiction 2011;106(9):1636-1643. https://doi.org/10.1111/j.1360-0443.2011.03436.x

65. Parry CD, Plüddemann A, Louw A, Leggett $T$. The 3-metros study of drugs and crime in South Africa: Findings and policy implications. Am J Drug Alcohol Abuse. 2004;30(1):167-185. https://doi.org/10.1081/ADA-120029872

66. Pasche S, Myers B. Substance misuse trends in South Africa. Hum Psychopharmacol: Clin Exp. 2012;27(3):338-341. https://doi.org/10.1002/hup.2228

67. Wechsberg WM, Wu LT, Zule WA, et al. Substance abuse, treatment needs and access among female sex workers and non-sex workers in Pretoria, South Africa. Subst Abuse Treat Prev Pol. 2009;4(1):11. https://doi.org/10.1186/1747-597X-4-11

68. Myers BJ, Louw J, Pasche SC. Inequitable access to substance abuse treatment services in Cape Town, South Africa. Subst Abuse Treat Prev Pol. 2010;5(1):28 https://doi.org/10.1186/1747-597X-5-28

69. Pacek LR, Mauro PM, Martins SS. Perceived risk of regular cannabis use in the United States from 2002 to 2012: Differences by sex, age, and race/ethnicity. Drug Alcohol Depend. 2015;149:232-244. https://doi.org/10.1016/j.drugalcdep.2015.02.009

70. Hopfer C. Implications of marijuana legalization for adolescent substance use. Substance Abuse. 2014;35(4):331-335. https://doi.org/10.1080/08897077.2014 943386

71. Elrod MM. Short-term increase in self-reported cannabis use to be expected. Can Med Assoc J. 2019;191(4):E108. https://doi.org/10.1503/cmaj.71135

72. Caulkins JP, Kilmer B, MacCoun RJ, Pacula RL, Reuter P. Design considerations for legalizing cannabis: Lessons inspired by analysis of California's Proposition 19 Addiction. 2012;107(5):865-871. https://doi.org/10.1111/j.1360-0443.2011.03561.x

73. Hall W, Weier M. Assessing the public health impacts of legalizing recreational cannabis use in the USA. Clin Pharmacol Therapeut. 2015;97(6):607-615. https:// doi.org/10.1002/cpt.110

74. Williams J, Bretteville-Jensen AL. Does liberalizing cannabis laws increase cannabis use? J Health Econ. 2014;36:20-32. https://doi.org/10.1016/j.jhealeco.2014.03.006

75. Ragab AR, Al-Mazroua MK. Passive cannabis smoking resulting in coma in a 16-month old infant. J Clin Case Rep. 2012;2(237):2. https://doi.org/10.4172/21657920.1000237 
76. Zarfin Y, Yefet E, Abozaid S, Nasser W, Mor T, Finkelstein Y. Infant with altered consciousness after cannabis passive inhalation. Child Abuse Negl. 2012;36(2):81. https://doi.org/10.1016/j.chiabu.2011.09.011

77. Cone EJ, Bigelow GE, Herrmann ES, et al. Non-smoker exposure to secondhand cannabis smoke. I. Urine screening and confirmation results. J Anal Toxicol. 2014;39(1):1-2. https://doi.org/10.1093/jat/bku116

78. Berthet A, De Cesare M, Favrat B, et al. A systematic review of passive exposure to cannabis. Forensic Sci Int. 2016;269:97-112. https://doi.org/10.1016/j. forsciint.2016.11.017

79. Hetzer $\mathrm{H}$, Walsh J. Pioneering cannabis regulation in Uruguay. NACLA Report Am. 2014;47(2):33-35. https://doi.org/10.1080/10714839.2014.11721851

80. Barry RA, Glantz S. A public health framework for legalized retail marijuana based on the US experience: Avoiding a new tobacco industry. PLoS Med. 2016;13(9):e1002131. https://doi.org/10.1371/journal.pmed.1002131

81. Wu LT, Zhu H, Swartz MS. Trends in cannabis use disorders among racial/ethnic population groups in the United States. Drug Alcohol Depend. 2016;165:181-90. https://doi.org/10.1016/j.drugalcdep.2016.06.002

82. Karriker-Jaffe. KJ. Areas of disadvantage: A systematic review of effects of arealevel socioeconomic status on substance use outcomes. Drug Alcohol Rev. 2011;30(1):84-95. https://doi.org/10.1111/j.1465-3362.2010.00191.x

83. Hammersley R. Pathways through drugs and crime: Desistance, trauma and resilience. J Crim Justice. 2011;39(3):268-272. https://doi.org/10.1016/j.jcrimjus. 2011.02.006

84. Plüddemann A, Flisher AJ, McKetin R, Parry C, Lombard C. Methamphetamine use, aggressive behavior and other mental health issues among high-school students in Cape Town, South Africa. Drug Alcohol Depend. 2010;109(1-3):14-19. https:// doi.org/10.1016/j.drugalcdep.2009.11.021

85. Secades-Villa R, Garcia-Rodríguez O, Jin CJ, Wang S, Blanco C. Probability and predictors of the cannabis gateway effect: A national study. Int J Drug Pol. 2015;26(2):135-142. https://doi.org/10.1016/j.drugpo.2014.07.011
86. Jouanjus E, Leymarie F, Tubery M, Lapeyre-Mestre M. Cannabis-related hospitalizations: Unexpected serious events identified through hospital databases. Br J Clin Pharmacol. 2011;71(5):758-765. https://doi.org/10.1111/j.1365-2125. 2010.03897.x

87. Meel BL. Trends in fatal motor vehicle accidents in Transkei region of South Africa. Med Sci Law. 2007;47(1):64-68. https://doi.org/10.1258/rsmmsl.47.1.64

88. Lewis C. Injury patterns in motor vehicle accident victims from a sample taken at the Southern Cluster Forensic Pathology Service. Doctoral dissertation. 2014 http://hdl.handle.net10539/14604

89. Rogeberg O, Elvik R. The effects of cannabis intoxication on motor vehicle collision revisited and revised. Addiction. 2016;111(8):1348-1359. https://doi.org/10. 1111/add.13347

90. Kalichman SC, Simbayi LC, Kagee A, et al. Associations of poverty, substance use, and HIV transmission risk behaviors in three South African communities. Soc Sci Med. 2006;62(7):1641-1649. https://doi.org/10.1016/j.socscimed.2005.08.021

91. Mulia N, Schmidt L, Bond J, Jacobs L, Korcha R. Stress, social support and problem drinking among women in poverty. Addiction. 2008;103(8):1283-1293. https:// doi.org/10.1111/j.1360-0443.2008.02234.x

92. Wasserman JA, Clair JM. At home on the street: People, poverty, and a hidden culture of homelessness. Social Forces. 2010;89(3):1088. https://doi.org/10.1353/ sof.2011.0021

93. Vassoler FM, Byrnes EM, Pierce RC. The impact of exposure to addictive drugs on future generations: Physiological and behavioral effects. Neuropharmacology. 2014;76:269-275. https://doi.org/10.1016/j.neuropharm.2013.06.016

94. Hajizadeh M. Legalizing and regulating marijuana in Canada: Review of potential economic, social, and health impacts. Int J Health Pol Manag. 2016;5(8):453. https://doi.org/10.15171/ijhpm.2016.63

95. Subritzky T, Pettigrew S, Lenton S. Issues in the implementation and evolution of the commercial recreational cannabis market in Colorado. Int J Drug Pol. 2016;27:1-2. https://doi.org/10.1016/j.drugpo.2015.12.001 